\title{
PENERAPAN MASSAGE ABDOMEN DAN MINUM AIR PUTIH HANGAT UNTUK MENCEGAH KONSTIPASI PADA ASUHAN KEPERAWATAN DENGAN KASUS STROKE DI RSUD POSO
}

\section{Application of Massage Abdomen and Warm White Drinking Water to Prevent Constipation in Nursing Care with Stroke Case in RSUD Poso}

\author{
Nirva Rantesigi ${ }^{1 *}$, Agusrianto ${ }^{1}$ \\ ${ }^{1}$ Jurusan Keperawatan Poltekkes Kemenkes Palu \\ (*Email Korespondensi: nirvarantesigi@gmail.com)
}

\begin{abstract}
ABSTRAK
Tindakan non farmakologis yang dapat mencegah dan mengatasi konstipasi adalah massage abdomen dan terapi minum air hangat $500 \mathrm{cc}$ pada pagi hari. Dengan melakukan massage mampu membantu mendorong pengeluaran feses dan menurunkan ketegangan otot abdomen. Tujuan penelitian ini adalah Penerapan Asuhan keperawatan pada kasus stroke. Penelitian ini merupakan jenis penelitian Studi kasus dengan menerapkan asuhan keperawatan komprehensif pada pasien. Hasil penelitian didapatkan data pasien belum BAB selama 4 hari, perut terasa penuh, ada keinginan untuk $\mathrm{BAB}$ namun sulit untuk keluar, bising usus 6 kali/menit. Tujuan dari asuhan keperawatan yaitu untuk mencegah dan mengatasi konstipasi dari konstipasi sedang menjadi konstipasi ringan. Diagnosa keperawatan konstipasi berhubungan dengan penurunan gastrointestinal. Intervensi keperawatan Manajemen konstipasi/ impikasi. Implementasi keperawatan melakukan massage abdomen dan terapi minum air hangat $500 \mathrm{cc}$ pada pagi hari. Evaluasi setelah 5 kali pemeberian intervensi pasien dapat BAB. Kesimpulan: Penerapan massage abdomen dan terapi minum air hangat $500 \mathrm{cc}$ dapat mencegah dan mengatasi konstipasi pada pasien stroke di RSUD Poso.
\end{abstract}

Kata Kunci : Stroke; konstipasi; Massage Abdomen; Terapi Minum Air Hangat

\section{ABSTRACT}

Non-pharmacological actions that can prevent and treat constipation are abdominal massage and therapy to drink $500 \mathrm{cc}$ of warm water in the morning. Doing massage can help encourage faeces and reduce abdominal muscle tension. The purpose of this study is the application of nursing care in stroke cases. This research is a type of case study research by applying comprehensive nursing care to patients. The results showed data of patients who have not defecated for 4 days, the stomach feels full, there is a desire to defecate but it is difficult to get out, bowel sounds 6 times / minute. The goal of nursing care is to prevent and overcome constipation, from moderate to mild constipation. Nursing diagnosis of constipation is related to decreased gastrointestinal. Nursing interventions Management constipation / impication. Implementation of nursing doing abdominal massage and therapy to drink $500 \mathrm{cc}$ of warm water in the morning. Evaluation after 5 times giving patient intervention can defecate. Conclusion: The application of abdominal massage and $500 \mathrm{cc}$ warm water drinking therapy can prevent and overcome constipation in stroke patients in Poso District General Hospital..

Keywords: Stroke; constipation; Abdomen Massage; Warm Drinking Therapy

\section{PENDAHULUAN}

Stroke merupakan penyebab tertinggi dari kecacatan dan kematian di seluruh dunia, menurut WHO, jumlah kematian di dunia akibat stroke sebanyak 6,15 juta dan menduduki peringkat kedua di dunia setelah penyakit jantung iskemik ${ }^{(1)}$. Berdasarkan Riskesdas tahun 2018, prevelensi penyakit stroke di Indonesia sebesar 10,9\%, dan untuk sulawesi tengah prevelensi penyakit stroke sebesar $10 \%{ }^{(2)}$. Kasus stroke di Kabupaten Poso pada tahun 2017 tercatat 603 kasus, mengalami penurunan pada tahun 2018 sebanyak 369 kasus. Berdasarkan hasil survay awal di lokasi penelitian yaitu RSUD Poso tahun 2017 jumlah penderita stroke yang di rawat di Rumah Sakit Umum Poso sebanyak 287 pasien, pada tahun 2018 berdasarkan data 
yang didapat dari bulan Juli s/d bulan Desember jumlah penderita stroke sebanyak 199 pasien, dan untuk tahun 2019 pada bulan januari terdapat penderita stroke sebanyak 11 pasien $^{(3)(4)(5)}$.

Stroke adalah suatu sindrom klinis yang ditandai dengan hilangnya fungsi otak secara akut dan dapat menimbulkan kematian. Salah satu Manifestasi klinis dari stroke gangguan keseimbangan tubuh dan kelemahan pada setengah bagaian tubuh atau hemiparese ${ }^{\left({ }^{(6)}\right.}$. Hemiparese adalah kondisi ketika salah satu sisi tubuh terjadi kelemahan. Kondisi tersebut bila berkepanjangan dapat berakibat buruk diantaranya beresiko untuk mengalami luka tekan, kontraktur sendi, osteoporosis, penurunan kekuatan otot dan konstipasi. Konstipasi merupakan defekasi yang tidak teratur serta terjadi pengerasan pada feses ${ }^{(7)}$. Pada pasien stroke konstipasi terjadi karena, kurangnya aktivitas fisik yang memperlama waktu transit feses di kolon, penurunan tonus otot abdomen, dan penurunan motilitas gastrointestinal ${ }^{(8)}$.

Salah satu terapi yang terbukti untuk mencegah konstipasi adalah massage abdomen dan minum air hangat. Massage merupakan suatu tindakan mengelus, menggosok, dan menekan pada bagian tubuh tertentu untuk memberikan rasa nyaman dan mengurangi rasa sakit. Massage abdomen dapat menurunkan konstipasi melalui beberapa mekanisme yang berbeda-beda antara lain dengan menstimulasi sistem persyarafan simpatis sehingga dapat menurunkan tegangan pada otot abdomen serta memberikan efek pada relaksasi sfingter ${ }^{(9)}$.

Massage abdomen mampu mencegah terjadinya konstipasi pada pasien stroke. Selain massage abdomen, air putih hangat juga terbukti efektif untuk mencegah konsipasi. Air putih hangat dapat memberikan Refleks gastrokolik yang mampu menstimulasi otot polos kolon sehingga meningkatkan motilitas kolon dan mencegah terjadinya konstipasi (9)(10).

Berdasarkan Penelitian yang dilakukan oleh Yasmara, et al menunjukan bahwa mengkonsumsi air putih pagi hari dapat mengatasi konstipasi pada pasien stroke. Dengan demikian massage abdomen yang dikombinasikan dengan terapi air putih merupakan alternatif yang tepat untuk mencegah konstipasi ${ }^{(11)}$.

\section{METODE PENELITIAN}

Penelitian ini merupakan jenis penelitian study kasus yang berlokasi di ruangan Neuro Stroke Center RSUD Poso dan waktu penetian dilakukan pada tanggal 08 Mei 2019. Pada penelitian yang dilakukan melibatkan satu pasien yang mengalami Non Hemoragik Stroke, dengan menggunakan baby oil untuk melakukan massage abdomen.

\section{HASIL}

Dari analisa data subjektif: Keluarga mengatakan klien sudah 4 hari belum BAB, klien mengatakan ada rasa $\mathrm{BAB}$ namum tidak bisa keluar, klien megatakan tidak bisa $\mathrm{BAB}$ dengan posisi berbaring, klien mengatakan perutnya terasa penuh. Objektif : klien tidak mampu mengeluarkan feses, bising usus 6 kali/menit, distensi abdomen maka peneliti menegakkan diagnose konstipasi berhungungan dengan penurunan motalitas gastrointestinal, dengan tujuan pengendalian gejala konstipasi dengan target 5. Peneliti pengambil NIC pengendalian gejala konstipasi karena diharapkan setelah 6 kali pemberian intervensi pasien mampu melakukan BAB. Adapun untuk intervensi peneliti mengangkat manajemen konstipasi atau impikasi, intervensi uang dilakukan yaitu Memonitor tanda dan gejala konstipasi, lakukan tindakan non farmakologis (massage abdomen), tawari makanan ringan (buah-buahan yang dapat merangsang usus), intruksikan pasien untuk minum air hangat pada pagi hari, dan kolaborasi pemberian terapi.

Berdasarkan intervensi manajemen konstipasi pada diagnose konstipasi ada 25 intervensi dengan yang dapat diberikan pada pasien yang mengalami masalah konsipasi. Berdasarkan penelitian yang dilakukan, peneliti hanya menerapkan 5 intervensi keperawatan pada pasien, hal tersebut dikarenakan keterbatasan waktu dalam melakukan penelitian dan juga pemilihan intervensi yang diberikan untuk tercapainya tujuan dari masalah keperawatan. Peneliti memberikan NIC manajemen konstipasi atau impikasi karena susuai dengan kriteria untuk diberikan intervensi yaitu kooperatif suntuk 
diberikan massage, mampu menelan dan tidak mengalami trauma abdomen

Penelitian dilakukan selama 6 hari dan didapatkan hasil pasien lebih nyaman setelah diberikan intervensi massage dan minum air putih hangat, dan pada hari ke 5 pasien sudah mampu $\mathrm{BAB}$.

\section{PEMBAHASAN}

Penulis menginstruksikan pasien untuk minum air hangat 500 cc pada pagi hari kemudian penulis melakukan massage abdomen dengan tujuan merangsang gerakan peristaltik pada lambung, maka rangsangan dari regangan lambung ini melalui saraf otonom ekstrinsik menjadi pemicu utama gerakan massa di kolon melalui refleks gastrokolik dan massage abdomen ${ }^{(12)}$. Dan massage abdomen dengan tujuan Massage abdomen dapat menurunkan konstipasi melalui beberapa mekanisme yang berbeda-beda antara lain dengan menstimulasi sistem persyarafan parasimpatis sehingga dapat menurunkan tegangan pada otot abdomen, meningkatkan motilitas pada sistem pencernaan, meningkatkan sekresi pada sistem intestinal serta memberikan efek pada relaksasi sfingter ${ }^{(8)}$. Hal tersebut sejalan dengan penelitian sebelumnya yang dilakukan oleh Theresia et al menunjukan bahwa massage abdomen mampu mencegah terjadinya konstipasi pada pasien yang mengalami stroke, Penelitian lain yang dilakukan oleh Ginting et al menunjukan bahwa massage abdomen dan minumair putih hangat mampu mengatasi konstipasi pada pasien stroke ${ }^{(13)}$. Asuhan keperawatan memfokuskan pada pemenuhan kebutuhan dasar manusia melalui tahap pengkajian, diagnose keperawatan, intervensi keperawatan, implementasi dan evaluasi. Penulis akan membahas tentang pemeberian implementasi sesuai dengan masalah yang di dapat pada Asuhan Keperawatan dengan pasien stroke dan pemberian intervensi Massage abdomen dan terapi minum air hangat untuk mencegah konstipasi pada asuhan keperawatan Ny. S dengan Non Hemoragik Stroke (NHS) di ruangan Neuro Stroke Center RSUD Poso.

Sebelum melakukan penerapan intervensi, peneliti terlebih dahulu melakukan anamnese pada tanggal 07 Mei 2019, peneliti memilih pasien berdasarkan kriteria untuk dilakukan massage abdomen dan terapi minum air angat 500 cc yaitu pasien dengan Stroke non hemoragik, ada masalah konstipasi, dan mampu untuk melelan. Pada pukul 14.00 peneliti mendapatkan pasien $\mathrm{Ny}$. $\mathrm{S}$ yang memiliki kriteria tersebut, kemudian peneliti menjelaskan maksut dan tujuan pemilihan Ny.S sebagai pasien penelitian, setelah itu peneliti menjelaskan prosedur pelaksanaan massage abdomen yang akan diberikan pada pasien yaitu :

a. Massage abdomen akan diberikan selama 6 hari.

b. Sebelum dilakukan massage abdomen pasien diminta untuk meminum $500 \mathrm{cc}$ air hangat pada pagi hari, sebelum pasien sarapan pagi. Alasannya massage abdomen tidak dapat diberikan pada saat keadaan perut terisi karena akan mengakibatkan pasien muntah dan memang sebaiknya massage dilakukan saat perut dalam keadaan kosong.

c. Massage dilakukan selama $10-20$ menit, dengan menggunakan baby oil sebagai pelumas.

d. Posisi saat dilakukan massage yaitu fowler atau terlentang.

e. Massage dilakukan menggunakan tangan dengan tehnik Effleurage yaitu gerakan mengusap pada daerah abdomen untuk merangsang peristaltic usus.

Setelah menjelaskan prosedur tindakan massage abdomen kemudian peneliti meminta persetujuan pasien untuk menjadi pasien penelitian pada inform consent. Kemudian peneliti melakukan kontrak waktu untuk hari berikutnya melakukan penerapan intervensi massage abdomen dan minum air hangat. Adapun pemberian intervensi sebagai berikut :

1) Pada hari pertama tanggal 08 mei 2019 intervensi dimulai pada pukul 06.00 WIT, peneliti mengintruksikan pada pasien untuk meminum air hangat terlebih dahulu $500 \mathrm{cc}$, namun pasein hanya mampu menghabiskan $300 \mathrm{cc}$, dan minum air hangat akan dilanjutkan setelah pemberian intervensi. Kemudian peneliti melakukan massage abdomen selama 15 menit, dan menanyakan respon pasien selama diberikan massage. setelah 15 menit pasien kembali meminum $200 \mathrm{cc}$ air hangat, peneliti melakukan pengkajian Skala Constipation Assessment Scale hari pertama nilai 4 dari 8 . Evaluasi 
pasien belum $\mathrm{BAB}$ dan masih sulit untuk mengeluarkan feses, bising usus $6 \mathrm{kali} /$ menit.

2) Pada hari kedua tanggal 09 mei 2019 intervensi dimulai pada pukul 06.00 , pasien menghabiskan $500 \mathrm{cc}$ air hangat diminum sejak bangun tidur pada pukul 05.00. Dilakukan massage abdomen selama 15 menit. Evaluasi Constipation Assessment Scale hari kedua nilai 2 dari 8 , bising usus 7 kali/menit, pasien belum BAB.

3) Pada hari ketiga tanggal 10 mei 2019, intervensi dimulai pada pukul 06.15 , pasien menghabiskan $500 \mathrm{cc}$ air hangat. Dilakukan massage abdomen selama 15 menit. Evaluasi pasien belum BAB, bising usus 7 kali permenit, Constipation Assessment Scale hari pertama nilai 2 dari 8 .

4) Pada hari keempat tanggal 11 mei 2019, intervensi dimulai pada pukul 06.15 , pasien menghabiskan $500 \mathrm{cc}$ air hngat, dilakukan massage abdomen selama 15 menit. Evaluasi pasien belum BAB, bising usus 7 kali permenit, Constipation Assessment Scale hari pertama nilai 2 dari 8 .

5) Pada hari kelima tanggal 12 mei 2019, intervensi dimulai pada pukul 06.15 , pasien menghabiskan $500 \mathrm{cc}$ air hangat, dilakukan massage abdomen, evaluasi : pasien sudah BAB 2 kali dengan konsistensi padat dan lunak. Constipation Assessment Scale hari kelima nilai 1 dari 8 , bising usus 10 $\mathrm{kali} / \mathrm{menit}$

6) Pada hari keenam pada tanggal 13 mei 2019, dimulai pada pukul 06. 15, pasien menghabiskan $500 \mathrm{cc}$ air hangat, dilakukan massage abdomen selama 10 menit. Pasien BAB 1 kali dengan konsistensi lunak, bising usus $14 \mathrm{kali} / \mathrm{menit}$, Constipation Assessment Scale hari pertama nilai 1 dari 8.

\section{KESIMPULAN DAN SARAN}

Setelah menerapkan terapi nonfarmakologis yaitu dengan melakukan massage abdomen dan minum air hangat selama 6 hari. Evaluasi pasien mampu BAB pada hari ke 5. Dan terbukti massage abdomen dan minum air hangat dapat mencegah dan mengatasi konstipasi. Penelitian ini menyarankan agar terapi ini bisa dilakukan untuk mencegah dan mengatasi konstipasi

\section{DAFTAR PUSTAKA}

1. Word Health Organization. Global Stroke Report 2016. Switzerland: World Helath Organization; 2016.

2. Kementerian Kesehatan R.I. Riset Kesehatan Dasar 2018. Jakarta: Badan Penelitian dan Pengembangan Kesehatan Kementerian Kesehatan R.I; 2018.

3. Rumah Sakit Umum Daerah Poso. Laporan Kasus Stroke Tahun 2017. Poso: Rumah Sakit Umum Daerah Poso; 2017.

4. Rumah Sakit Umum Daerah Poso. Laporan Kasus Stroke Tahun 2018. Poso: Rumah Sakit Umum Daerah Poso; 2018.

5. Rumah Sakit Umum Daerah Poso. Laporan Sementara Kasus Stroke Januari 2019. Poso: Rumah Sakit Umum Daerah Poso; 2019.

6. Yueniwati Y. Deteksi Dini Stroke Iskemia dengan Pemeriksaan Ultrasonografi Vaskular dan Variasi Genetika. Malang: Universitas Brawijaya Press; 2014.

7. Muttaqin A, Sari K. Gangguan Gastrointestinal: Aplikasi Asuhan Keperawatan Medikal Bedah. Jakarta: Salemba Medika; 2011.

8. Sinclair M. The Use of Abdominal Massage to Treat Chronic Constipation. J Bodyw Mov Ther [Internet]. 2011 Oct [cited 2019 Nov 25];15(4):436-45. Available from: https://linkinghub.elsevier.com/retrieve/pii/S13 60859210001063

9. Lämås K, Lindholm L, Stenlund H, Engström B, Jacobsson C. Effects of Abdominal Massage in Management of Constipation-A Randomized Controlled Trial. Int J Nurs Stud [Internet]. 2009 Jun [cited 2019 Nov 25];46(6):759-67. Available from: https://linkinghub.elsevier.com/retrieve/pii/S00 20748909000108

10. Theresia SIM, Setyani FAR, Estri AK. Pengaruh Massage Abdominal dalam Upaya Pencegahan Konstipasi pada Pasien yang Menjalani Rawat Inap di Rumah Sakit Panti Nugroho Yogyakarta. Sekol Tinggi Ilmu Kesehat Panti Rapih Yogyak [Internet]. 2016;17-34. Available from: http://stikespantirapih.ac.id/download/MANUS KRIP\%20BU\%20SIWI.pdf

11. Yasmara D, Irawaty D, Kariasa IM. Water Consumption on The Morning to Constipation of Patient with Immobilization. J Ners [Internet]. 2013;8(1). Available from: https://ejournal.unair.ac.id/JNERS/article/view/3880

12. Lunding JA, Tefera S, Bayati A, Helge Gilja $\mathrm{O}$, Mattsson H, Hausken T, et al. PressureInduced Gastric Accommodation Studied with a New Distension Paradigm. Abnormally Low Accommodation Rate in Patients with Functional Dyspepsia. Scand J Gastroenterol 
[Internet]. 2006 Jan [cited 2019 Nov 25];41(5):544-52. Available from: http://www.tandfonline.com/doi/full/10.1080/0 0365520500353723

13. Ginting D, Waluyo A, Sukmarini L. Mengatasi Konstipasi Pasien Stroke dengan Masase Abdomen dan Minum Air Putih Hangat. J Keperawatan Indones [Internet]. 2015 Mar 27 [cited 2019 Nov 25];18(1):23-30. Available from:

http://jki.ui.ac.id/index.php/jki/article/view/394 